\title{
Envisioning sustainable water futures in a transdisciplinary learning process: combining normative, explorative, and participatory scenario approaches
}

\author{
Flurina Schneider $\cdot$ Stephan Rist
}

Received: 25 February 2013/ Accepted: 6 October 2013/Published online: 20 October 2013

(C) Springer Japan 2013

\begin{abstract}
Competing water demands for household consumption as well as the production of food, energy, and other uses pose challenges for water supply and sustainable development in many parts of the world. Designing creative strategies and learning processes for sustainable water governance is thus of prime importance. While this need is uncontested, suitable approaches still have to be found. In this article we present and evaluate a conceptual approach to scenario building aimed at transdisciplinary learning for sustainable water governance. The approach combines normative, explorative, and participatory scenario elements. This combination allows for adequate consideration of stakeholders' and scientists' systems, target, and transformation knowledge. Application of the approach in the MontanAqua project in the Swiss Alps confirmed its high potential for co-producing new knowledge and establishing a meaningful and deliberative dialogue between all actors involved. The iterative and combined approach ensured that stakeholders' knowledge was adequately captured, fed into scientific analysis, and brought back to stakeholders in several cycles, thereby facilitating learning and co-production of new knowledge relevant for both stakeholders and scientists. However, the approach also revealed a number of constraints, including the enormous flexibility required of stakeholders and scientists in order for them to
\end{abstract}

Handled by Zafar Adeel, UNU-International Network on Water, Environment and Health (INWEH), Canada.

F. Schneider $(\square) \cdot$ S. Rist

Centre for Development and Environment (CDE), and Institute of Geography, University of Bern, Hallerstrasse 10, 3012 Bern, Switzerland

e-mail: flurina.schneider@cde.unibe.ch

URL: http://www.cde.unibe.ch truly engage in the co-production of new knowledge. Overall, the study showed that shifts from strategic to communicative action are possible in an environment of mutual trust. This ultimately depends on creating conditions of interaction that place scientists' and stakeholders' knowledge on an equal footing.

Keywords Socio-economic scenarios - Visions of the future - Water use - Water governance .

Participatory · Transdisciplinary

\section{Introduction}

Climate change and other forms of global change pose challenges to water supply and water governance in many parts of the world. Freshwater might become one of the most severely limited resource in the future due to competing water demands for household consumption, food and energy production, and other uses (Kuylenstierna et al. 1997; Wiek and Larson 2012). Accordingly, sustainable governance of water resources is a central part of sustainable development (Franks and Cleaver 2009). But what exactly is "sustainable" water governance? Defining this is a difficult task. The problem lies in the highly normative and abstract definition of sustainability. According to the widely accepted definition formulated in the Brundtland Report, “... sustainability implies a concern for social equity between generations, a concern that must logically be extended to equity within each generation" (WCED 1987). In order to make this concept operational, the abstract principles of intra- and inter-generational equity need to be broken down into more concrete guidelines that spell out what it means to make existing water governance arrangements more sustainable. 
Sustainable water governance as a deliberative process

Lessons learnt during past efforts to implement the principles of sustainability in natural resource governance provide some guidance. For example, experience has shown that sustainability is best viewed as the outcome of a participatory process in which people involved in the production, use, and regulation of a natural resource come to a shared and contextualised understanding of what sustainability means and how this concept should be used to reorient existing institutional arrangements and practices towards more sustainable governance of the resource in question. This process of contextualisation aims at achieving “... a certain fit of the overarching, global goals of sustainability and the local circumstances, which means that the sustainability goals need to be reformulated for the local situation" (Hartmuth et al. 2008:262).

Consequently, applying the principles of sustainability to water resource governance requires a participatory process in which these principles are adapted to the context of the concrete socioecological system involved. In this sense, Wiek and Larson (2012) define sustainable water governance "as the process that involves all relevant stakeholder groups in coordinating the water-related supply, delivery, use, and outflow activities in a way that ensures a sufficient and equitable level of social and economic welfare without compromising the viability and integrity of the supporting hydro-ecosystems in the long term."

However, both research and practice have shown that efforts to involve stakeholders can easily fail due to differences in their perceptions of the issue at stake and unequal power relations between them. Unequal power relations mean that actors do not have equal opportunities to voice their views and concerns in the process of negotiating and concretising a shared understanding of sustainability, and this can cause the outcome of stakeholder involvement to be flawed (Lawhon and Murphy 2012). The process of contextualisation must thus be not only participatory, but part of a deliberative dialogue between all relevant actors involved (Ray 1999). A deliberative process is understood as a process that allows actors to shift from strategic to communicative action in the sense of Habermas (Rist et al. 2006). This means changing the mode of interaction from primarily strategic action (based on actors' intention to accomplish their individual interests and predetermined ends) to communicative action (aimed at achieving a critical common understanding of what sustainability means and what consequences this has with regard to reorienting existing natural resource governance arrangements) (Rist et al. 2007). Drawing on the above lines of thinking, we define sustainable governance of water as follows: sustainable water governance is a deliberative process that involves all relevant stakeholder groups in (1) contextualising the general principles of sustainability; (2) developing a joint understanding of water-related problems and potentials; and (3) taking collective action to transform existing institutions regulating water supply, delivery, use, and outflow activities so as to ensure sufficient and equitable social and economic welfare without compromising the viability and integrity of the supporting hydro-ecosystems in the long term.

Sustainable water governance as transdisciplinary learning

Defining sustainable water governance as a deliberative process involving all relevant stakeholders means understanding it as a process of transdisciplinary learning (Hirsch Hadorn et al. 2006; Pohl and Hirsch Hadorn 2007). A growing strand of research proposes to conceive of knowledge creation in the context of sustainability-which is often characterised by complexity, uncertainty, and controversy-as a process of joint knowledge production and mutual learning between scientists and a broad range of stakeholders such as practitioners, managers, and policymakers (Aeberhard and Rist 2009; Daniell et al. 2010; Renner et al. 2013; Rist et al. 2007; Roux et al. 2006; Schneider et al. 2009). Accordingly, stakeholders are seen as partners in a joint research process in which their knowledge is "equally valuable to scientific knowledge" (Mobjörk 2010). Against this background, we conceive of scientific work as part of an overall societal process. Ideally, scientific work on water governance should contribute to social learning processes that aim for a negotiated transformation of the norms, rules, and power relations governing the use of water (Rist et al. 2007).

This implies that participatory processes related to sustainable water governance should allow scientists and stakeholders to jointly produce whatever novel knowledge is needed. This includes defining creative new goals for more sustainable water governance (target knowledge), as well as developing a strategy for achieving them (transformation knowledge); both require a proper understanding of how the related socioecological systems work (systems knowledge) (Hirsch Hadorn et al. 2006; Pohl and Hirsch Hadorn 2007).

Scenario approaches as a tool for transdisciplinary learning towards sustainable water governance

In this article we argue that scenario analyses can be a powerful tool for operationalising deliberative processes aimed at transdisciplinary learning for sustainable water governance (see also Swart et al. 2004). Scenarios can support actors in envisioning more desirable and sustainable futures and in devising transitions towards these futures (GEF 2013). 
Visioning and scenarios have been suggested as important tools for strategy development and planning by several authors (e.g. Pollard and Du Toit 2008; Daniell et al. 2010), and different water management initiatives have applied scenario methodologies. For example, the UN World Water Scenario programme developed global water visions (Cosgrove and Cosgrove 2012), and the Global Environment Facility (GEF) used visions of the future as important elements in their approach to tackle transboundary water problems (GEF 2013).

In research on water governance and use, however, scenario approaches are not very widespread. Despite the wealth of research on future climate change and its possible impacts on water resources (e.g. Beniston et al. 2011; Viviroli et al. 2011) socio-economic scenarios ${ }^{1}$ are rarely applied, especially at regional and local scales. Exceptions include the work of Lienert et al. (2005), Moriarty et al. (2010), Smits et al. (2004), Forsyth and Brooks (2011), Mylopoulos et al. (2012), and Rinaudo et al. (2012). Although socio-economic scenario analyses have become more frequent in recent years, their application is still rather unsystematic (March et al. 2012). Moreover, the scientific debate on the construction and application of socio-economic scenarios in the context of sustainable water governance has remained fairly limited (March et al. 2012).

A major challenge for research and action on sustainable water governance, however, is not only to consider the expected effects of environmental change (e.g. climate change), but to integrate possible socio-economic dynamics as well. This gives fundamental importance to the question of what types of scenario approach are most adequate-alone or in combination-to support deliberative processes towards sustainable water governance.

This article presents and discusses a conceptual approach to scenario building in the context of sustainable water governance, taking into account the knowledge and needs of both stakeholders and scientists. The approach was developed based on existing scientific literature and was tested and refined within the MontanAqua transdisciplinary research project on water governance in the context of global change in the driest region of the Swiss Alps.

Below, we briefly introduce the case study area and the methods we used for developing and testing the scenario approach. Then we discuss the suitability of existing scenario approaches for sustainable water governance. Subsequently, we present a conceptual approach to scenario development in the context of sustainable water

\footnotetext{
${ }^{1}$ In this article, the term 'socio-economic scenarios' is used as an umbrella term for scenarios that consider a broad range of social and economic, but also technological, cultural, and policy aspects as well as their interrelations.
}

governance, at the same time reflecting on our experiences during its application. Finally, we draw conclusions regarding the potentials and limitations of the approach.

Case study region and method

\section{Case study region}

The study region of Crans-Montana-Sierre in the Swiss canton of Valais is situated on a southern slope in the driest part of Switzerland and has experienced dynamic economic, tourism, and urban development over the last decades. It covers an altitudinal range between about $500 \mathrm{~m}$ and $3,000 \mathrm{~m}$ a.s.1. Annual precipitation increases with elevation, ranging from 500 to around 2,000 mm. Diversity of land use and land cover is another main characteristic. The lowest slopes are dominated by vineyards. Above them lies an area of extensively used farmland and expanding forests, with settlements that mainly house local people. At the medium altitudes, tourist resorts and recreational activities such as golf and skiing predominate. The highest part of the study region is a typical alpine landscape. It is topped by the Plaine Morte, a plateau glacier, which is partly drained through karstic underground formations and linked to various springs in the region. The main anthropogenic influences on the hydrological system are reservoirs (Tseuzier dam and various lakes) and a complex network of traditional water channels (bisses) and water pipes for water supply. Water is used mainly for consumption, agriculture, hydropower, and tourism (e.g. snow production, irrigation of golf course). The study area corresponds to the territory of 11 communes (local municipalities) and has a variety of formal and informal water governance structures in place, including a multitude of different water rights.

Both climate change and socio-economic development might significantly modify the supply and consumption of water in the future and thereby fuel existing conflicts of interest or create new ones. It must be assumed that the general water supply in the study region will become even scarcer, and that its seasonal distribution may change significantly (Beniston et al. 2011). Against this background, water management practices and strategies need to be fundamentally revisited. The overall objective of the MontanAqua transdisciplinary research project is to develop strategies for moving towards more sustainable governance of water resources in the study region together with the actors involved (Schneider 2011). Accordingly, these strategies are being developed in a transdisciplinary process of co-producing systems, target, and transformation knowledge (Hirsch Hadorn et al. 2006; Pohl and Hirsch Hadorn 2007). The project has been running since 2010 and will end in 2013. 


\section{Methods}

Development of the scenario approach started with an analysis of the literature and the identification of specific criteria that might support deliberative processes aimed at transdisciplinary learning for sustainable water governance. Based on the identified criteria, we then evaluated existing scientific literature on scenario approaches in natural resource and land use planning as well as water governance and use. The resulting scenario approach including the identified criteria and the literature review is presented in the section below on Suitability of existing scenario approaches. The various steps of the scenario approach and the tools and methods applied are presented in A conceptual approach to water use scenarios for more sustainable development.

Testing the scenario approach meant assessing methods, potentials, and limitations of transdisciplinary co-production of knowledge involving our own team of researchers. We tackled this challenge by means of an iterative selfreflexive procedure. This procedure is compatible with socalled Mode 2 knowledge production (Gibbons et al. 1994), which is considered an epistemological centrepiece of transdisciplinary knowledge production. Mode 2 knowledge production takes place in the context of application and provides "socially robust knowledge" (Nowotny et al. 2001) rather than knowledge that is validated only through classical scientific procedures. According to Nowotny (2000), "socially robust knowledge is the product of an intensive and continuous interaction [...] between people and environments, between applications and implications. The vision developed here is processual and open-ended." Our procedure also corresponds to the model of action research (Elden and Levin 1991; Checkland and Holwell 1998), which intends researchers to get involved in the flux of real-world situations, "aiming at mutual, collaborative, critical and deliberation-based interaction about specific issues and between researchers and non-academic actors" (Rist et al. 2006).

Our systematic analysis started with the beginning of the scenario exercise and was based on qualitative methods from social sciences (Flick 2005), including participatory observation, rapid appraisals at the end of certain meetings, and formal and informal group discussions during and after meetings. All main steps of the scenario exercise were documented (audio recordings, flipcharts, and/or research diary) and assessed by the researchers through individual and collective reflection. First analyses took place immediately following each step. These analyses were structured by the first author of this article, who actively participated in all activities, observed the processes, organised spaces for joint reflection among the participants, and documented the results. In this way, potentials and constraints of each step conducted were systematically assessed. The overall analysis was concluded at an externally moderated workshop after the scenario process had been finalised. In this workshop, the researchers assessed strengths and limitations of the overall transdisciplinary process. The analysis presented here is hence the result of a collective learning process which evolved from the continuous iteration of applying steps of the developed scenario approach, reflecting on the experiences made, and discussing the implications for transdisciplinary learning. Findings from this analysis as well as the resulting modifications in the procedure are presented in the section below entitled " $\mathrm{A}$ conceptual approach to water use scenarios for more sustainable development".

\section{Suitability of existing scenario approaches}

Given that socio-economic scenarios are relatively rare in studies on water use and governance, we begin with a brief introduction to what a scenario is. Scenarios can be described as vivid stories or 'snapshots' of what might happen in the future (Wollenberg et al. 2000; Nassauer and Corry 2004). They generally include "a description of the present situation, a number of alternative futures, and possible pathways connecting the present with the images of the future" (Nassauer and Corry 2004). Scenarios do not indicate what the future will look like; instead, they are meant to stimulate creative thinking (Wollenberg et al. 2000) and enable decision-makers "to anticipate their reactions to different future possibilities, to anticipate time frames beyond the immediate future, and to make choices" (Nassauer and Corry 2004).

Scenarios are thus different from forecasting. While the latter aims to describe what the future is likely to be, generally by extrapolating current trends, scenarios "describe alternative futures or contrasting trends that may be very different from the present" (Nassauer and Corry 2004). Forecasting requires historical precedents, regularities of cause and effect, and data availability, and is limited to fairly short time periods (Deshler 1987 in Wollenberg et al. 2000; Moran et al. 2007). Scenarios, by contrast, are more useful in situations where uncertainty is high and cannot be controlled-for example, when dealing with long time periods or with regional development issues-but also where there is a need for novel ideas to address particularly difficult policy challenges, or where current changes point to a future that is very different from the past (Nassauer and Corry 2004).

A review of the rich literature on scenario analysis concerning natural resource and land use reveals a vast variety of approaches. They differ in their aims (e.g. analysis of a phenomenon or learning support), their methods 
of construction (e.g. prospecting or projecting), the sources of information they tap (e.g. scientific observation or decision-makers' knowledge), the role of stakeholders (e.g. active or passive), the starting points of pathways (e.g. present or future), the explicitness of value orientation (e.g. normative or explorative scenarios), and the degree to which they reflect either current conditions and trends or unexpected or extreme events (Wollenberg et al. 2000).

What is required of a scenario approach that is intended to support deliberative processes aimed at transdisciplinary learning for sustainable water governance? Based on the ideas explored in the Introduction, such an approach should:

- Enable balanced cooperation between stakeholders and scientists, valuing their respective knowledge equally.

- Provide novel and inspiring insights that go beyond the usual way of thinking of each actor group.

- Facilitate a continuous learning process between stakeholders and scientists through joint reflection and debate on

- The present condition of the water governance system and its possible future evolution (systems knowledge),

- What sustainable development in the region might be (target knowledge), and

- How current unsustainable arrangements and practices can be transformed to more sustainable ones (transformation knowledge).

- Provide procedures and outcomes that are meaningful for both stakeholders and scientists. More specifically, this means that the scenarios must be suitable for numeric modelling and/or scientific reflection, and that their use must be of value in stakeholders' decisionmaking processes.

A review of the existing scenario studies revealed that a meaningful design that fulfils the above requirements might be achieved by extending and combining different scenario approaches-namely normative, explorative and participatory approaches. We briefly introduce these three scenario approaches in the sections below.

\section{Normative and explorative scenarios}

Normative scenarios envision desired futures that should be, and that represent tangible goals to explore. These envisioned futures may not yet exist, but they are plausible and can thus inspire policymakers by providing images of a future that meets a variety of sustainability goals (Nassauer and Corry 2004). Normative scenarios are usually expressed in storylines; this means that they represent qualitative data. Normative scenario approaches are most appropriate for developing target knowledge regarding sustainability goals. For instance, Forsyth and Brooks (2011) envisioned a future society in which the quality of life is high even though the use of fresh water is greatly reduced compared to the present. A normative scenario approach was also applied by Moriarty et al. (2010). In their case, the normative images of the future were constructed by the stakeholders and thus represent the stakeholders' values and preferences.

Explorative scenarios describe potential future developments based on an analysis of the present situation and logical chains of plausible events and their interactions ('what happens if') (Walz et al. 2007). These are best suited for producing systems knowledge, that is, knowledge about the present condition of a water governance system and its possible evolution in the future. In the field of water research, this approach has been taken by Harmancioglu et al. (2008) and Mylopoulos et al. (2012), who explored the implications of different development strategies and changes in driving forces such as demographic, socio-economic, technological, or agricultural development for the sustainability of future resource demand and governance. To do so, they first analysed the current status and then built a business-as-usual scenario based on current trends; from this, they finally derived alternative scenarios based on optimistic or pessimistic assumptions regarding policy effects, infrastructural efficiency, demographic trends, and the development of crops and irrigated areas. Other authors, such as Lienert et al. (2005) or Kim and Furumai (2012), took similar approaches to urban water management, domestic water use, and evaluating the effectiveness of different water supply technologies. Explorative scenarios proved to be particularly helpful in assessing the implications of changes in selected factors. However, several scholars noted that explorative scenarios are often not very popular with stakeholders as they are not sufficiently linked to their everyday life.

Both normative and explorative scenario approaches can be used to develop transformation knowledge. In the case of normative scenarios, transformation knowledge can be developed through "backcasting", that is, by mapping out pathways - policies, strategies, and programmes - that link the current situation to the envisioned sustainable future. This requires an analysis of the current situation (systems knowledge) after the vision of the future is formulated. Forsyth and Brooks (2011) stress that there is no unique pathway for any given situation; rather, there are always a variety of ways to achieve sustainability, depending on stakeholders' preferences. In the case of explorative scenarios, transformation knowledge can be produced by assessing the outcomes of the different scenarios and their driving forces. However, sustainability values are not made explicit in explorative scenarios. Consequently, in order to 
produce transformation knowledge from an explorative scenario, sustainability goals first have to be clarified.

\section{Participatory scenarios}

Scenario approaches in sustainability research are regularly combined with stakeholder involvement, for example to improve scenario quality by taking into account local people's systems knowledge (Walz et al. 2007); to analyse people's preferences regarding the future (target knowledge) (Soliva et al. 2008); to identify possible measures and tools for reaching a particular future (transformation knowledge) (Forsyth and Brooks 2011); or to stimulate learning processes among stakeholders (Wollenberg et al. 2000). Despite all these advantages, scholars also stress that scenario building based on strong stakeholder involvement may fail to stimulate new ways of thinking about the future among stakeholders, as certain ecological, economic, or cultural characteristics may remain unimaginable to them (Nassauer and Corry 2004).

In the water governance literature, detailed descriptions of participatory scenario approaches are rare (March et al. 2012). Du Toit et al. (2011), GEF (2013), Daniell et al. (2010) and Moriarty et al. (2010) propose a participatory scenario approach as a key means of water resources management and planning, by which all stakeholders involved develop water governance strategies based on visioning, problem analysis, and scenario building. In these approaches, stakeholders produce systems, target, and transformation knowledge. Other authors focus on one specific type of knowledge, namely systems knowledge. Lienert et al. (2005) involved experts for describing possible evolutions of the Swiss water sector, and Rinaudo et al. (2012) organised stakeholder workshops for assessing three groundwater policy scenarios. By doing so, both authors combined stakeholders' and scientists' knowledge in specific ways. Lienert et al. (2005) combined a literature survey with expert interviews and workshops; Rinaudo et al. (2012) built the participatory scenario exercise on policy scenarios which had been predefined by scientists.

However, participatory scenario approaches are hardly ever used to systematically link scientific and stakeholders' assessments (including modelling) and at the same time facilitate capacity building and learning among multiple stakeholders. (A similar conclusion was drawn in Walz et al. 2007 with regard to regional development research.) A valuable exception is the SCENES project, which has applied the so-called Story and Simulation approach (Alcamo 2008), linking storyline revision and modelling work in an iterative process (Kok et al. 2011; Schaldach et al. 2012). This approach turns out to be quite similar to the approach presented in this article.

Table 1 gives an overview of the approaches discussed in this section, focusing on their key features from the point of view of transdisciplinary learning for sustainable water governance.

\section{A conceptual approach to water use scenarios for more sustainable development}

In the following we present the scenario approach that we developed and applied in the MontanAqua project, and describe how it is embedded in the related overall learning process aimed at co-producing sustainable water governance strategies. The approach combines participatory construction of normative and explorative scenarios. According to the analysis presented in Table 1, this combination holds the highest potential for establishing a meaningful and learning-oriented dialogue between researchers and stakeholders and adequately considering both stakeholders' and scientists' systems, target, and transformation knowledge.

A normative scenario approach was taken to develop target knowledge with regard to sustainable water governance. As mentioned in the Introduction, we assume that

Table 1 Overview of selected scenario types and their key features

\begin{tabular}{|c|c|c|c|c|}
\hline $\begin{array}{l}\text { Scenario } \\
\text { type }\end{array}$ & Main objective & Pertinence & $\begin{array}{l}\text { Whose } \\
\text { knowledge }\end{array}$ & $\begin{array}{l}\text { Types of knowledge } \\
\text { produced }\end{array}$ \\
\hline Normative & Envision desirable futures & $\begin{array}{l}\text { When novel (sustainable) development goals } \\
\text { are needed }\end{array}$ & $\begin{array}{l}\text { Scientists } \\
\text { and/or } \\
\text { stakeholders }\end{array}$ & $\begin{array}{l}\text { Target knowledge, } \\
\text { sometimes } \\
\text { transformation } \\
\text { knowledge }\end{array}$ \\
\hline Explorative & $\begin{array}{l}\text { Investigate 'what happens if' by } \\
\text { analysing the current situation and } \\
\text { logical chains of plausible events }\end{array}$ & $\begin{array}{l}\text { When the impacts of alternative } \\
\text { developments need to be evaluated; when } \\
\text { unexpected changes are likely to occur }\end{array}$ & $\begin{array}{l}\text { Scientists } \\
\text { and/or } \\
\text { stakeholders }\end{array}$ & $\begin{array}{l}\text { Systems knowledge, } \\
\text { sometimes } \\
\text { transformation } \\
\text { knowledge }\end{array}$ \\
\hline Participatory & $\begin{array}{l}\text { Integrate stakeholders' knowledge; } \\
\text { facilitate learning }\end{array}$ & $\begin{array}{l}\text { When there is a need for stakeholders' } \\
\text { knowledge and values as well as social } \\
\text { learning between all actors }\end{array}$ & $\begin{array}{l}\text { Mostly } \\
\text { stakeholders }\end{array}$ & $\begin{array}{l}\text { Systems, target, and/or } \\
\text { transformation } \\
\text { knowledge }\end{array}$ \\
\hline
\end{tabular}




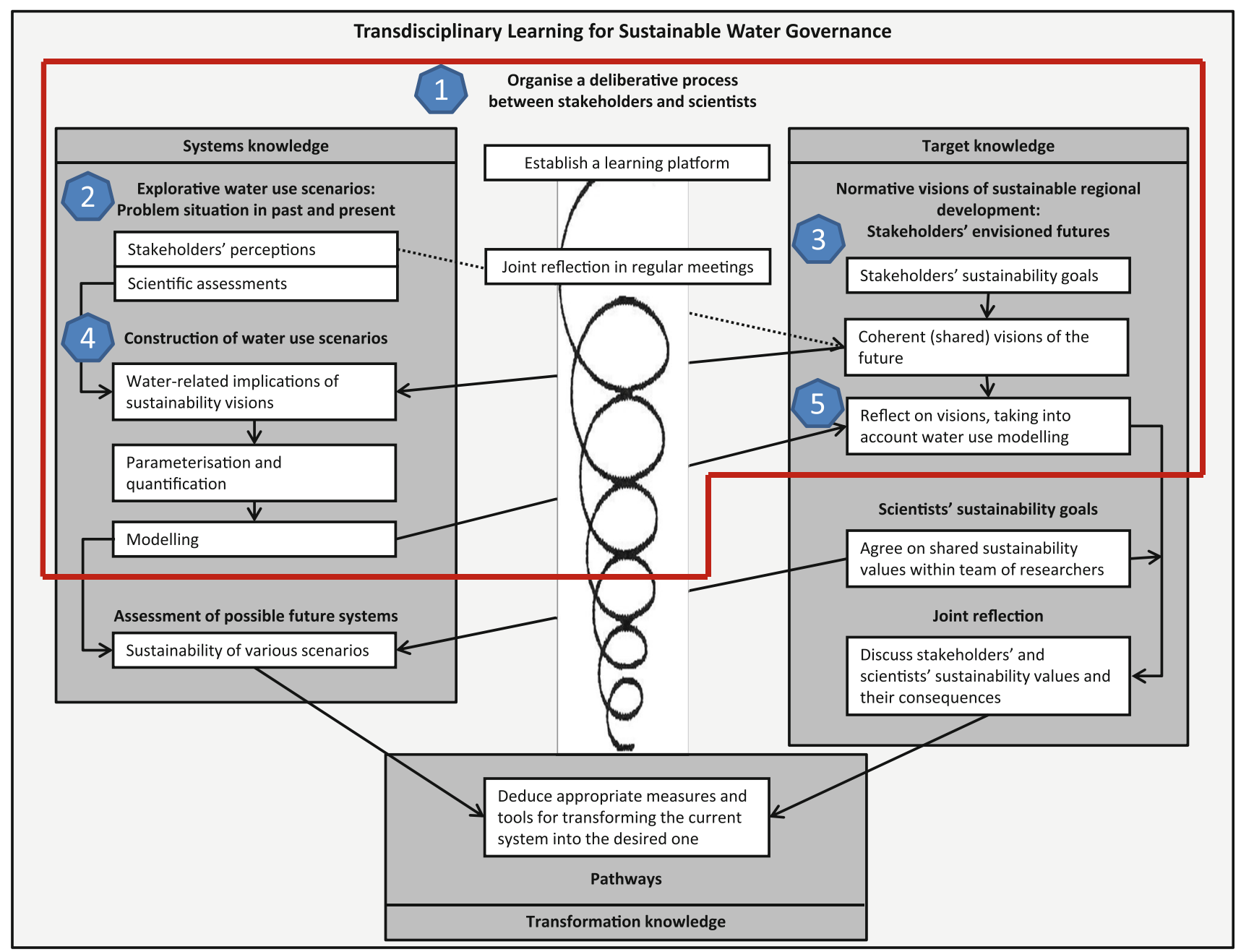

Fig. 1 Conceptual approach to water use scenarios for more sustainable development and main tasks involved

the general principles of sustainability have to be placed in and adapted to the local context in a deliberative process. Moreover, we believe that the sustainability of water governance arrangements can only be assessed meaningfully by referring to the broader context of sustainable regional development. For these reasons, we organised a participatory process aimed at developing visions of sustainable regional development. These development visions later served as a frame of reference for sustainable water governance. The objective of the normative scenario approach presented here was to clarify stakeholders' sustainability goals and to encourage a dialogue about these goals, since building commonly shared visions of future development is considered crucial to sustainable water governance (Moriarty et al. 2010). Co-production of new target knowledge considering not only stakeholders' but also scientists' sustainability goals did not take place within this normative scenario approach, but at a later stage of the project; it is therefore not addressed in the present article (see Fig. 1).
An explorative scenario approach was taken to develop systems knowledge for sustainable water governance. This included assessing the water-related implications of the sustainability visions developed within the normative scenario approach. Based on an analysis of the current situation (scientific assessments and stakeholders' perceptions), we constructed and modelled water use scenarios, taking into account changes in driving forces as defined by the normative visions of the future. This explorative scenario approach made it possible to estimate water demands for potential future developments and identify key leverage points. Moreover, it enabled simulation of water demands for the previously developed normative visions of the future, thereby further encouraging the dialogue about these normative visions-for example, when the simulation showed that a certain vision would entail water demands that could impair the system's overall sustainability.

Figure 1 offers an overview of the scenario approach as applied in the MontanAqua project so far-denoted by the red frame-and shows how it was embedded in an overall 
learning process for sustainable water governance. The figure visualises how learning for sustainable water governance is organised as an iterative and cyclic process based on transdisciplinary co-production of systems, target, and transformation knowledge. In this process, both stakeholders and scientists contribute to the production of different forms of knowledge; they can learn from each other and redevelop their respective knowledge, including their values and norms.

The scenario approach follows a procedure that comprises the following five tasks: (1) organisation of a continuous learning platform to facilitate interactions between stakeholders and researchers; (2) analysis of the problem in the past and present, taking into account both stakeholders' perceptions and scientific assessments; (3) parallel participatory development of normative visions of sustainable regional development for the year 2050; (4) subsequent translation of these visions of regional development into explorative water use scenarios as a basis for simulating future water demands; and (5) joint reflection by stakeholders and scientists, informed by these simulations, on the sustainability of the water governance system currently in place.

These five tasks are presented in more detail in below. For each task, we describe the main steps, methods applied, and lessons learned, focusing more on methods of transdisciplinary knowledge production than on the disciplinary methods applied, for example, to model the water use scenarios. Results related to the contents of the scenario process are presented in summarising figures and tables in order to illustrate the methods applied and lessons learned. They are not the focus of this article and have been published elsewhere (Bonriposi 2013).

\section{Organising a continuous deliberative process}

between stakeholders and scientists

Interactions between stakeholders and scientists in the MontanAqua project take place at different levels and with varying intensity, ranging from informing or consulting each other to jointly developing new knowledge. Information (e.g. through newspaper articles) and consultation (e.g. through interviews) mainly serve the purpose of involving the broader public and a wide range of experts. The main activities aimed at knowledge co-production and deliberative discourse, however, take place in a smaller stakeholder group called RegiEau.

\section{Establishing the stakeholder group}

Approach Establishing an appropriate stakeholder group is a crucial task in this kind of endeavour (Renner et al. 2013): the group's composition has a substantial influence on the outcomes of a scenario exercise, both in terms of topics considered and with regard to stakeholders' acceptance of the exercise. The presence of a diversity of stakeholders helps to identify relevant topics and facilitates the implementation of results at a later stage, as stakeholders become involved and start to believe in the project during work in the group. With this in mind, we first conducted a stakeholder analysis to avoid marginalising or passing over important stakeholder groups (Palomo et al. 2011; Reed 2008; Renner et al. 2013). This analysis drew on previous research regarding water use and governance in the study region (Reynard 2000), as well as a project kick-off meeting where a broad range of local and regional stakeholders were consulted. On this basis, we identified the following actor groups: representatives of the main water users (domestic water use, tourism, agriculture, viticulture, hydropower) and pressure groups (ecology and landscape), water managers, decision-makers, and water owners. This list was confirmed in a meeting with the presidents of the communes involved, whom we consulted in their function as elected representatives of the population. The selection of individuals representing each actor group was largely delegated to the respective groups' institutions (e.g. the farmers' association or the communes). In this way, we succeeded in building the RegiEau stakeholder group, comprised of 12 representatives of the key actor groups.

Lessons learned Stakeholder selection was a complex and time-consuming process, as we had to consider not only the restricted availability of the key stakeholders, but also existing conflicts and tensions between them (including an ongoing court case about a conflict between biodiversity protection and the construction of a new megatourism project). The strong involvement of local stakeholders in identifying key actors and selecting their representatives was crucial to successfully building a stakeholder group that covered a broad range of stakeholders, including the two main water governance associations. This was a novel achievement at that time. Moreover, the participants of the RegiEau group were broadly accepted as representatives of their institutions. However, as we will show later, this advantage came with the disadvantage of participants sometimes being very strongly bound to specific institutional interests, which made it difficult at times to come to an agreement within the group.

\section{Maintaining continuous interaction and learning}

Approach The importance of maintaining continuous interaction and learning has been stressed by many scholars (e.g. Daniell et al. 2010; Renner et al. 2013). Consequently, 
after establishing an appropriate stakeholder group, we organised regular group meetings in the different communes involved. These meetings took place about 3 times per year and enabled researchers and stakeholders to openly debate the potentials, contradictions, and challenges of sustainable water governance in the region, always taking into account the newest advances and implications of the MontanAqua project. Researchers presented the results of their studies and put them up for discussion; stakeholders contributed their ideas, knowledge, and visions. All tasks described below-from vision building to scenario construction-were presented, worked on, and/or discussed in the RegiEau group. Moreover, the meetings provided an opportunity for all participants to reflect about each other's values and knowledge and to co-produce new knowledge.

Lessons learned More details on the methods applied and their potentials and limitations for facilitating continuous learning and knowledge production are given in the following sections.

Analysing the situation in the past and the present

Situation analysis is part of many proposed scenario approaches. It is often used as a starting point for explorative scenarios (e.g. Harmancioglu et al. 2008; Mylopoulos et al. 2012) as well as for scenario application in water management initiatives (e.g. Du Toit et al. 2011; GEF 2013)

\section{Setting the context: stakeholders' perceptions of the problem}

Approach At the very beginning of the project, we conducted a first stakeholder workshop to learn about stakeholders' perception of the water situation and their need for new knowledge. In this workshop, the stakeholders discussed current and expected future problems, potentials, and constraints of water governance in the Crans-MontanaSierre region. At a later stage, we conducted a series of semi-structured interviews with a broad range of water managers, decision-makers, and water users in order to complement and refine the findings from the initial workshop. Table 2 summarises the most important results of these assessments.

Lessons learned Stakeholders' early involvement in jointly identifying the problem and putting it in concrete terms, and the opportunity this offered for researchers to learn from stakeholders' systems knowledge were invaluable for the subsequent tasks. These early interactions enabled all participants to grasp the complexity of the
Table 2 Main issues according to stakeholders' perceptions

\begin{tabular}{|c|c|}
\hline Topics & Main issues discussed \\
\hline Problems & $\begin{array}{l}\text { Water stress is a highly relevant issue, and periods of } \\
\text { water stress are becoming increasingly frequent }\end{array}$ \\
\hline Constraints & $\begin{array}{l}\text { Infrastructure, water rights, upstream/downstream } \\
\text { riparian communes, borders, protection zones and } \\
\text { residential zones, residual flows, competition } \\
\text { between different water uses, historical tensions } \\
\text { between the communes }\end{array}$ \\
\hline Potentials & $\begin{array}{l}\text { Retention capacities (especially of the water supply } \\
\text { dam) and the wide and partially interconnected } \\
\text { system of pipelines and irrigation channels }\end{array}$ \\
\hline $\begin{array}{l}\text { Knowledge } \\
\text { needs }\end{array}$ & $\begin{array}{l}\text { Seasonal and actor-specific variations of water } \\
\text { availability, their implications for future } \\
\text { developments (e.g. the end of the Tseuzier } \\
\text { hydropower concession in 2037), and the role of the } \\
\text { Plaine Morte glacier (e.g. how long will the glacier } \\
\text { function as a reliable water reservoir, and what } \\
\text { portion of its water is drained to the Crans- } \\
\text { Montana-Sierre region?) }\end{array}$ \\
\hline
\end{tabular}

situation, to better understand crucial aspects such as the importance of the social dimension and power relationships, to establish contact with local stakeholders, and to become familiar with their different perspectives. Most importantly, however, these interactions helped to establish trust and commitment between the researchers and the various actors from the project region.

\section{Scientific assessments}

Approach Informed by the stakeholder workshop described above and subsequent workshops for participatory scenario development (see section below on Developing visions of sustainable regional development), the research team conducted various disciplinary and interdisciplinary studies to collect information about those aspects of the water governance system that had been identified as relevant. A fundamental task was to analyse the past and current status of water resources, water and land uses, water governance practices, and regional development. This was achieved in 4 interrelated doctoral studies along with 26 master's and bachelor's studies. The overall effort was coordinated and supported by a postdoctoral researcher, who was in charge of assuring adequate levels of synthesis in the individual studies. Research results were, and continue to be, presented and discussed on a regular basis in the RegiEau stakeholder group. Table 3 lists the various studies; their results have been, or will be, published in separate articles.

Lessons learned The researchers involved agreed that the extended interdisciplinary assessments conducted by human and physical geographers, hydrologists, engineers, 
Table 3 Overview of scientific assessments of the present system

\begin{tabular}{|c|c|}
\hline Topics & Studies \\
\hline Water resources & $\begin{array}{l}\text {-Modelling of the natural water balance based } \\
\text { on an extensive hydrometeorological network } \\
\text {-Implications of climate change on Plaine } \\
\text { Morte Glacier (Huss 2013) Investigation of } \\
\text { the karstic environment (underground water } \\
\text { transfer system) based on 3D modelling and } \\
\text { tracer experiments (ISSKA 2010) }\end{array}$ \\
\hline Land uses & $\begin{array}{l}\text {-Creation of historical and current land use } \\
\text { maps using satellite image analysis (Niklaus } \\
\text { 2012) } \\
\text {-Analysis of the relationship between water } \\
\text { resources and land use } \\
\text {-Assessment of how different agricultural land } \\
\text { governance practices influence the water } \\
\text { system }\end{array}$ \\
\hline Water uses & $\begin{array}{l}\text {-Study of the main water uses (domestic } \\
\text { consumption, energy production, agriculture, } \\
\text { viticulture, and tourism) and their spatial print } \\
\text { (Bonriposi 2013) } \\
\text {-Quantification of current needs for each type of } \\
\text { use at a seasonal scale (Reynard and } \\
\text { Bonriposi 2012, Bonriposi 2013) }\end{array}$ \\
\hline $\begin{array}{l}\text { Water governance } \\
\text { practices }\end{array}$ & $\begin{array}{l}\text {-Study of water governance practices from } \\
\text { decision-making to action } \\
\text {-Evaluation of institutional and legislative } \\
\text { frameworks } \\
\text {-Analysis of the social relationships between } \\
\text { actors: alliances, antagonisms, and conflicts }\end{array}$ \\
\hline $\begin{array}{l}\text { Regional } \\
\text { development }\end{array}$ & $\begin{array}{l}\text {-Analysis of statistical data concerning various } \\
\text { aspects of regional development such as } \\
\text { population, housing, economic activities, etc. } \\
\text {-Identification of existing scenario studies } \\
\text { relevant to the study region } \\
\text {-Evaluation of policy documents }\end{array}$ \\
\hline
\end{tabular}

and sociologists were indispensable for grasping the complexity of the system. However, interdisciplinary collaboration was also challenging in terms of linking different scientific backgrounds, concepts, and languages (social and natural sciences), different kinds of data (qualitative and quantitative), and different spatial prints (hydrological units, areas of water use such as ski pistes, and areas of water management, e.g. by communes and common-pool resource management associations). Consequently, much emphasis was placed on social learning and communication between researchers.

But the scientific studies also proved to be of interest to the stakeholders. Presentations of results were generally followed by lively debates on their implications. Stakeholders were particularly interested in quantifications of water use by different user groups as well as on general regional information, for example on spring discharges. However, we also observed situations where scientific insights contested stakeholders' existing knowledge based on their personal experience. Handling the resulting tensions posed a particular challenge in facilitating learning within the group. In these situations it proved particularly relevant to openly discuss potentials and limitations of the chosen scientific methods.

Developing visions of sustainable regional development

Visions of sustainable regional development were developed in three steps. First, stakeholders' sustainability goals were identified. Subsequently, three alternative visions of future development were formulated. On this basis, participants finally developed a shared vision of sustainable regional development.

\section{Identifying stakeholders' sustainability goals}

Approach In order to identify stakeholders' sustainability goals and visions of the future we conducted a half-day workshop with the RegiEau group and several interviews with members of the group who were unable to participate in the workshop (2), as well as a broad range of water users, such as inhabitants (41), farmers (20), and tourist managers (15). We opened the workshop with an icebreaker exercise where participants were asked to express their mental associations with 12 images showing different forms and uses of water (glacier, lake, irrigation, etc.). The purpose of this exercise was to initiate group interaction, to create awareness that everybody has valuable knowledge to contribute to the workshop, to broaden the range of possible topics, and to establish a link with the water issue. Subsequently, the participants were asked to envision the future development of the region as they wish their grandchildren to experience it when they are the participants' age. This question was designed to provoke thoughts about intergenerational equity. In a first step, the participants were given time to envision, map, and summarise their preferred future on cards (individual work). Then the participants were divided into two heterogeneous groups to compare and discuss their individual visions of the future. Moderators supported the groups in identifying key aspects of their visions and entering the related topics in a summarising table (Fig. 2). The issues and topics discussed did not necessarily have to have a direct relation to water; they included, optimal water management, but also public transport. Subsequently, each participant rated the topics listed in the table in terms of importance. After each group presented their outcomes to the other group, work continued in one single group again, with the aim that stakeholders with similar sustainability values construct $2-3$ alternative visions (see Developing a shared vision). 


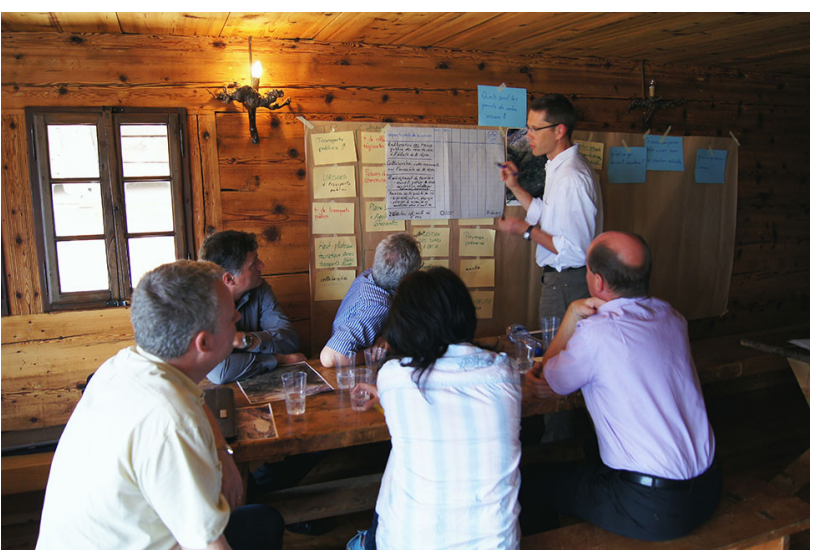

Fig. 2 Workshop for identifying stakeholders' development visions

Lessons learned The imagination exercises described above allowed participants to express and make explicit their individual sustainability goals; the task of summarising enabled them to gain a rapid overview of the most important topics and their relevance to different participants. However, the developed visions of the future remained rather 'traditional' and close to existing, everyday thinking due to fairly tight time constraints. In everyday life, most participants were used to look for pragmatic solutions rather than visionary ones. We assume that application of further creativity methods such as thought experiments or word games would have resulted in more visionary results. Furthermore, due to the heterogeneity of the participating stakeholders and the existing historical tensions between some of them it was difficult to find common ground for identifying coherent sets of alternative visions. Especially participants with a pronounced political position, such as the presidents of the communes, had trouble openly debating development alternatives that did not correspond to the position they advocate 'in real life'.

Approach Given that the RegiEau group was unable to formulate one or several agreed and coherent development visions during the workshop, they asked the researchers to identify three visions based on the workshop discussions and to present them to the group at the next meeting. To do so, the researchers analysed audio recordings of the discussions as well as the memory cards and summarising tables. On this basis, they identified elements that the participants had agreed on and elements that had remained controversial. Moreover, they also analysed the visions of the future that further stakeholders had expressed in interviews conducted after the group workshop as well as during the situation analysis (Analysing the situation in the past and the present) in order to broaden and consolidate the range of possible options. Based on these analyses, the researchers identified 12 key topics (demography, water
Table 4 Three overall development strategies

\begin{tabular}{|c|c|c|}
\hline Growth strategy & Stabilisation strategy & Moderation strategy \\
\hline $\begin{array}{l}\text { Growth is at the heart } \\
\text { of the region's } \\
\text { development. Mass } \\
\text { tourism, lucrative } \\
\text { activities, and } \\
\text { second homes are } \\
\text { the main focus. } \\
\text { Water resources } \\
\text { and landscape are } \\
\text { important, but not } \\
\text { top priorities. } \\
\text { Indeed, the } \\
\text { inhabitants of } \\
\text { Crans-Montana- } \\
\text { Sierre feel that } \\
\text { there is enough } \\
\text { water thanks to } \\
\text { engineering } \\
\text { measures (supply } \\
\text { management) }\end{array}$ & $\begin{array}{l}\text { Water and landscape } \\
\text { are among the } \\
\text { region's most } \\
\text { important } \\
\text { resources. They are } \\
\text { indispensable both } \\
\text { for tourism and for } \\
\text { the local } \\
\text { population's well- } \\
\text { being. For this } \\
\text { reason, regional } \\
\text { development in } \\
\text { Crans-Montana- } \\
\text { Sierre follows } \\
\text { alternative } \\
\text { approaches aimed } \\
\text { at more efficient } \\
\text { resource use. Water } \\
\text { management } \\
\text { focuses in } \\
\text { particular on } \\
\text { optimising water } \\
\text { consumption } \\
\text { (demand } \\
\text { management) }\end{array}$ & $\begin{array}{l}\text { Development in the } \\
\text { Crans-Montana- } \\
\text { Sierre region is } \\
\text { oriented primarily } \\
\text { towards improving } \\
\text { the quality of life } \\
\text { for residents and } \\
\text { visitors. Creating } \\
\text { jobs is just as } \\
\text { important as } \\
\text { maintaining an } \\
\text { adequate drinking } \\
\text { water supply and } \\
\text { conserving a } \\
\text { healthy cultural } \\
\text { landscape. Water } \\
\text { and landscape use } \\
\text { are in line with the } \\
\text { needs of the local } \\
\text { economy }\end{array}$ \\
\hline
\end{tabular}

consumption, spatial planning, tourism, agriculture, viticulture, hydropower, nature, water infrastructure, institutions/collaboration, public transport, and quality of life/ jobs). Furthermore, in order to reflect the diversity of the different stakeholders' normative orientations, they formulated three overall development strategies that give different priorities to issues of landscape and natural resources in relation to socio-economic concerns: growth, stabilisation, and moderation (Table 4).

Subsequently, the researchers ordered the contested development issues expressed by the stakeholders according to these three general development strategies and by key topic. The resulting table was complemented by alternatives proposed by the researchers, with a particular focus on putting more 'moderation' options up for discussion.

In Vision 1, which is oriented towards economic growth and supply management, all aspects that are considered as economically lucrative are assumed to grow (general water consumption, building activities, mass tourism, viticulture, and hydropower production). In contrast, aspects that are not economically lucrative are assumed to decrease (agriculture and water for nature). This vision includes no attempts to save water or to improve the existing water governance approaches. It is a business-as-usual scenario. Vision 2-the stabilisation strategy-focuses on optimised management of land and water resources; however, it does not fundamentally question the development pathway 
followed up to the present. Unlike Vision 1, it attributes equal value also to economically less lucrative aspects, such as agriculture and nature. It includes various attempts to save water and introduces various measures of demand management (e.g. improved network connection and collaboration). Vision 3 strives for a development pathway that heads in a fundamentally different direction from the one pursued so far, by reducing the demand for water and land while improving the living conditions for local people. Water saving efforts and improvements in water governance are more ground-breaking, including, for example, a reduction of the skiing area (no snow cannons), local rainwater harvesting, and continuous collaboration for the benefit of all inhabitants of the region. A short version of the development visions is presented in Table 5 below.

The challenge was to identify and elaborate three development visions that were coherent and plausible, sufficiently distinct to enable scientific modelling, and which the different actors would be able to identify with. As proposed by Soliva (2007), coherence between key topics within each vision was guaranteed by qualitative reasoning within the interdisciplinary team of researchers (for example, agriculture and viticulture may both increase their productivity, but they cannot both increase their surfaces).

The visions developed by the scientists were presented and discussed at a next stakeholder workshop. Not surprisingly, the stakeholders could not fully identify with one of the three visions. Instead, they preferred to rearrange and combine the strategies for the different key topics in new ways (for example, they opted for a stabilisation strategy when it came to tourism, but preferred a moderation strategy with regard to agriculture). Nonetheless, the entire group clearly expressed the wish to develop a shared vision. While the stakeholders' intention to build a joint vision was welcomed by the researchers, it also posed new challenges, as the research project's schedule called for proceeding with the modelling tasks. Researchers and stakeholders agreed to start modelling the available visions and at the same time continue to search for a shared vision of regional development within the RegiEau group.

Lessons learned Although the researchers did not succeed in elaborating sets of alternative visions that were fully endorsed by the stakeholders, the approach facilitated a group process that resulted in the wish to come to an agreement on contested development issues. This wish might have been elicited by a preceding presentation and discussion of scientific findings about glacier melt and discharge behaviour that will affect the region considerably. This illustrates very well how discussion of first results of the explorative scenario approach enriched normative scenario development. During this process, the group atmosphere changed considerably, shifting from a rather distant and cautious attitude to a supportive one based on a certain level of trust and commitment. This might also be the result of the researchers having shown the stakeholders that they take their perspectives seriously and that the stakeholders can truly influence the collaboration processes and outcomes. This, however, requires a high amount of flexibility of the researchers involved and the research designs applied.

\section{Developing a shared vision}

Approach The quest for a shared vision was continued at a next meeting of the RegiEau group. At this meeting, the three visions were presented once again, and the stakeholders were asked to mark their preferred strategy for each key topic with green stickers (one sticker per key topic). Furthermore, they were given the option to mark 'no-go developments' with red stickers (each participant had no more than five stickers to prevent blockage of the discussion). The resulting picture (Fig. 3) was surprisingly clear and displayed a strong preference for the stabilisation and moderation strategies.

The group then agreed that topics with less than two dissenting statements were to be considered as decided upon (unless one participant requested a debate). As a result, only four topics with diverging opinions had to be further discussed (land use planning, agriculture, nature, and infrastructure). These topics were regrouped and/or completely reformulated according to the agreement eventually reached by the group. The resulting shared vision is similar to the stabilisation strategy proposed by the researchers, with several adjustments in the direction of the moderation strategy (see Table 5). At the end of the meeting, the group's approval of the shared vision was so stable that they agreed to publish the vision in the local newspaper. Some days later, however, one key stakeholder - the president of the water-richest communevetoed the agreed wording concerning the need to renegotiate existing water rights.

Lessons learned The procedure quickly revealed uncontested issues and provided an entry point for jointly constructing consensus based on elements discussed during former meetings. In a truly deliberative dialogue, the group agreed on a shared vision of sustainable regional development. Interestingly, they included several aspects of the moderation strategy that had been introduced by the researchers (Developing a shared vision) and which thus go beyond the goals for the future that they themselves developed in the first step (Identifying stakeholders' sustainability goals).

However, once the participants had returned to their 'real-life' institutional contexts shaped by strategic 
Table 5 Three alternative visions of regional development prepared by the research team and the shared vision of the RegiEau stakeholder group (short version)

\begin{tabular}{|c|c|c|c|c|}
\hline Topic & $\begin{array}{l}\text { Vision 1: growth } \\
\text { strategy }\end{array}$ & Vision 2: stabilisation strategy & Vision 3: moderation strategy & Vision of the RegiEau group \\
\hline Demography & $\begin{array}{l}\text { Strong population } \\
\text { growth }\end{array}$ & Slight population growth & Population decrease & Slight population growth \\
\hline $\begin{array}{l}\text { Water } \\
\text { consumption }\end{array}$ & $\begin{array}{l}\text { No water-saving } \\
\text { efforts } \\
\text { Drinking water is at } \\
\text { times used for } \\
\text { irrigation }\end{array}$ & $\begin{array}{l}\text { Water supply has become } \\
\text { more efficient } \\
\text { Separate drinking water and } \\
\text { irrigation water networks }\end{array}$ & $\begin{array}{l}\text { Water supply has become more } \\
\text { efficient } \\
\text { Separate drinking water and } \\
\text { irrigation water networks }\end{array}$ & $\begin{array}{l}\text { Water supply has become more } \\
\text { efficient } \\
\text { Separate drinking water and } \\
\text { irrigation water networks, } \\
\text { including in residential areas }\end{array}$ \\
\hline $\begin{array}{l}\text { Spatial } \\
\text { planning }\end{array}$ & $\begin{array}{l}\text { Unrestrained } \\
\text { building activities } \\
\text { (under current } \\
\text { legislation) }\end{array}$ & $\begin{array}{l}\text { Densification } \\
\text { Construction of second homes } \\
\text { is restricted } \\
\text { Construction of small } \\
\text { apartment buildings is } \\
\text { encouraged }\end{array}$ & $\begin{array}{l}\text { Building industry has developed } \\
\text { into reconstruction and energy- } \\
\text { efficient renovation industry } \\
\text { Some previous building areas } \\
\text { have been re-zoned as "non- } \\
\text { developable" areas }\end{array}$ & $\begin{array}{l}\text { Densification } \\
\text { Construction of second homes is } \\
\text { restricted } \\
\text { Construction of small apartment } \\
\text { buildings is encouraged }\end{array}$ \\
\hline Tourism & $\begin{array}{l}\text { Mass tourism based } \\
\text { mainly on skiing } \\
\text { and golf (new } \\
\text { snow cannons and } \\
\text { golf greens) }\end{array}$ & $\begin{array}{l}\text { Tourism has become more } \\
\text { attractive all year round } \\
\text { Skiing area has been reduced }\end{array}$ & $\begin{array}{l}\text { Tourism industry focuses on } \\
\text { "soft" tourism based on } \\
\text { gastronomic and outdoor } \\
\text { activities linked with a broad } \\
\text { range of cultural and } \\
\text { educational offers }\end{array}$ & $\begin{array}{l}\text { Tourism has become more } \\
\text { attractive all year round } \\
\text { Skiing area has been reduced }\end{array}$ \\
\hline Agriculture & $\begin{array}{l}\text { Agriculture is not a } \\
\text { priority } \\
\text { Farming has } \\
\text { become } \\
\text { increasingly } \\
\text { extensive }\end{array}$ & $\begin{array}{l}\text { Agriculture plays important } \\
\text { role in food production } \\
\text { (especially meat) }\end{array}$ & $\begin{array}{l}\text { Agriculture is highly important to } \\
\text { the region and primarily serves } \\
\text { tourism, nature conservation, } \\
\text { and landscape maintenance }\end{array}$ & $\begin{array}{l}\text { Agriculture is highly important to } \\
\text { the region and serves tourism, } \\
\text { nature conservation, and } \\
\text { landscape maintenance }\end{array}$ \\
\hline Viticulture & $\begin{array}{l}\text { Viticulture has been } \\
\text { intensified } \\
\text { (increased } \\
\text { profitability) }\end{array}$ & $\begin{array}{l}\text { Viticulture is continued at } \\
\text { same level of intensity (high- } \\
\text { quality wine) }\end{array}$ & $\begin{array}{l}\text { Viticulture has become } \\
\text { increasingly extensive (high- } \\
\text { quality wine, biodiversity) }\end{array}$ & $\begin{array}{l}\text { Viticulture is continued at same } \\
\text { level of intensity (high-quality } \\
\text { wine) }\end{array}$ \\
\hline & Sprinkler irrigation & Drip irrigation & Drip irrigation & Drip irrigation \\
\hline Hydropower & $\begin{array}{l}\text { Hydropower } \\
\text { production is of } \\
\text { utmost } \\
\text { importance } \\
\text { All rivers' } \\
\text { hydropower } \\
\text { potentials are } \\
\text { fully tapped }\end{array}$ & $\begin{array}{l}\text { Hydropower production has } \\
\text { high priority, but other water } \\
\text { needs are considered equally } \\
\text { important (irrigation, } \\
\text { drinking water, etc.) }\end{array}$ & $\begin{array}{l}\text { Hydropower production is } \\
\text { important, but the goal is to } \\
\text { reduce energy consumption and } \\
\text { diversify energy sources }\end{array}$ & $\begin{array}{l}\text { Hydropower production is } \\
\text { important, but the goal is to } \\
\text { reduce energy consumption and } \\
\text { diversify energy sources }\end{array}$ \\
\hline Nature & $\begin{array}{l}\text { Legal minimum } \\
\text { residual flow has } \\
\text { been lowered }\end{array}$ & $\begin{array}{l}\text { Legal minimum residual flow } \\
\text { has remained the same }\end{array}$ & $\begin{array}{l}\text { Legal minimal residual flow has } \\
\text { been increased }\end{array}$ & $\begin{array}{l}\text { Legal minimum residual flow has } \\
\text { remained the same }\end{array}$ \\
\hline $\begin{array}{l}\text { Water } \\
\text { infrastructure }\end{array}$ & $\begin{array}{l}\text { Water infrastructure } \\
\text { networks are } \\
\text { being expanded }\end{array}$ & $\begin{array}{l}\text { Unified network for drinking } \\
\text { water }\end{array}$ & $\begin{array}{l}\text { Unified network for drinking } \\
\text { water } \\
\text { Households harvest and store } \\
\text { rainwater locally }\end{array}$ & $\begin{array}{l}\text { Unified network for drinking } \\
\text { water } \\
\text { Households harvest and store } \\
\text { rainwater locally }\end{array}$ \\
\hline \multirow[t]{2}{*}{$\begin{array}{l}\text { Institutions } \\
\text { and } \\
\text { collaboration }\end{array}$} & $\begin{array}{l}\text { Intercommunal } \\
\text { collaboration } \\
\text { continues }\end{array}$ & $\begin{array}{l}\text { Collaboration between the } 11 \\
\text { communes has improved and } \\
\text { water supply management } \\
\text { has been centralised } \\
\text { Water rights have been } \\
\text { renegotiated }\end{array}$ & $\begin{array}{l}\text { The } 11 \text { communes have joined } \\
\text { their efforts and created an } \\
\text { association that ensures water } \\
\text { supply for the benefit of all } \\
\text { inhabitants of the region }\end{array}$ & $\begin{array}{l}\text { The } 11 \text { communes have joined } \\
\text { their efforts and created an } \\
\text { association that ensures water } \\
\text { supply for the benefit of all } \\
\text { inhabitants of the region }\end{array}$ \\
\hline & $\begin{array}{l}\text { Water pricing is } \\
\text { based on flat rate }\end{array}$ & $\begin{array}{l}\text { Water pricing is based on } \\
\text { consumption }\end{array}$ & $\begin{array}{l}\text { Water pricing is based on } \\
\text { consumption (graded system) }\end{array}$ & $\begin{array}{l}\text { Water pricing is based on } \\
\text { consumption (graded system) }\end{array}$ \\
\hline
\end{tabular}




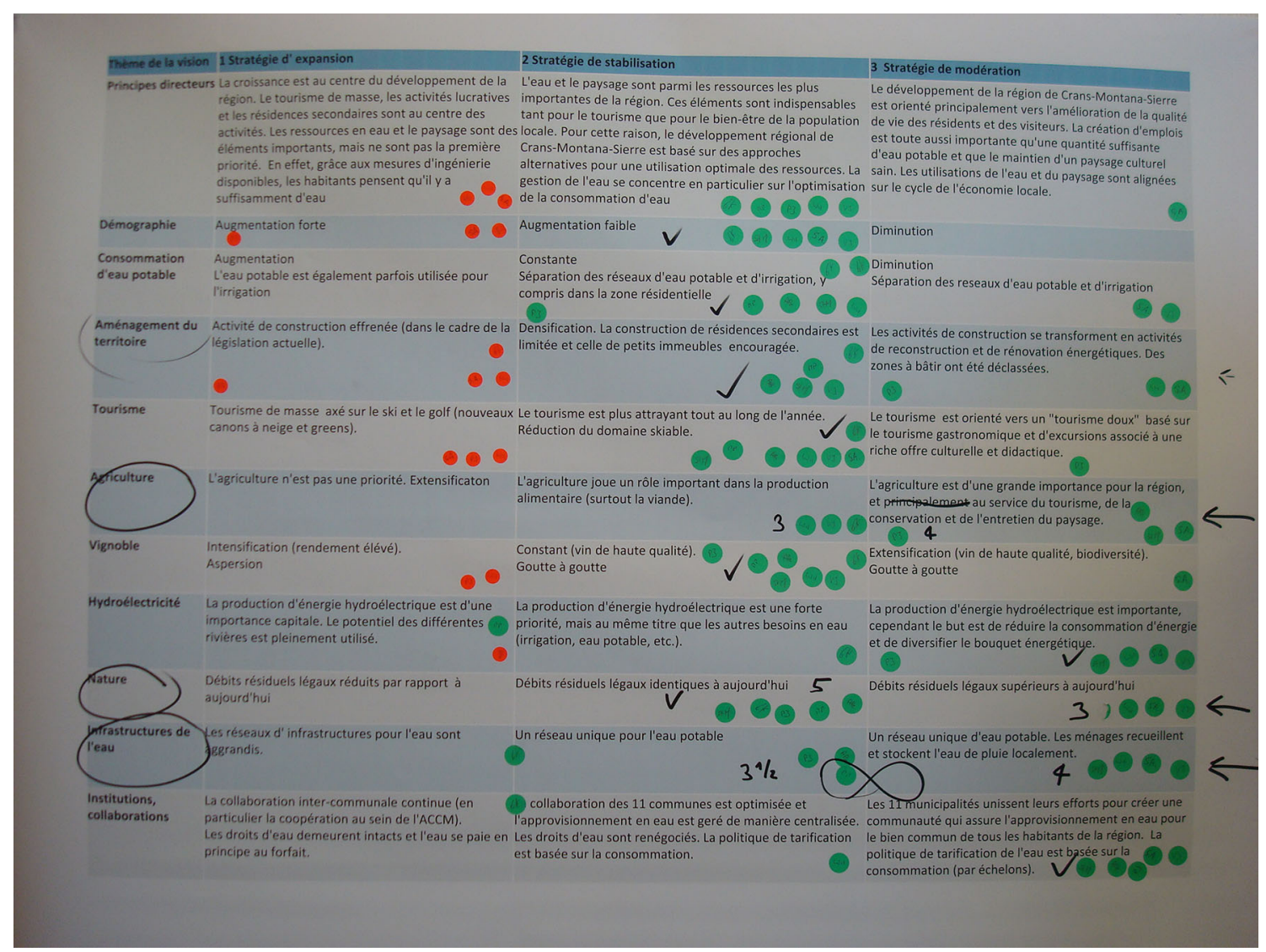

Fig. 3 Priorities of the members of the RegiEau group concerning the proposed visions of regional development. Green stickers Preference, red stickers "no go"

reasoning and existing power relationships, they had again to link up with the positions defended there. Not surprisingly, this affected the important issue of water rights, which is highly contested in public debates. In order not to jeopardise their consensus, the RegiEau group subsequently decided to cancel the issue of water rights from their joint vision. While there is still disagreement concerning the important issue of water rights, development of the joint vision can be regarded as a big step forward, as the participants developed a new joint understanding in many other important domains.

From visions of regional development to explorative water use scenarios

The next task was to construct explorative water use scenarios. This was done mainly by the interdisciplinary team of researchers and is therefore not the focus of this article. In the following we give a brief summary, focussing above all on the links between the different scenario approaches. The actual modelling of the water use scenarios is described elsewhere (Bonriposi 2013).

\section{Approach}

In order to enable modelling of potential future water demands, the development visions had to be translated from qualitative storylines comprising general issues of regional development into quantitative water use scenarios. This took place in an iterative process, during which the different approaches continuously informed each other. Before launching the participatory process for developing the visions, we had prepared a list of parameters required for modelling which provided a certain guidance in the process of vision development. Once the visions had been formulated, we analysed them with regard to their implications for water use, taking into account existing literature and stakeholders' knowledge. Based on this analysis, we determined the main drivers of future water demand (Table 6).

Finally, the scientists in charge of modelling proceeded to construct and model water use scenarios corresponding to the different development visions. This required the identification of suitable parameters and their interrelationships. Table 7 gives an overview of the chosen 
Table 6 Overview of the main drivers of future water demand based on the visions of regional development

\begin{tabular}{ll}
\hline $\begin{array}{l}\text { Type of water } \\
\text { demand }\end{array}$ & Main drivers of water demand \\
\hline Drinking water & $\begin{array}{l}\text { Demographic development, number and seasonal } \\
\text { distribution of tourists visiting the region, water- } \\
\text { saving efforts, water use efficiency, separation of } \\
\text { drinking water and irrigation water networks, } \\
\text { and governance measures (water rights, pricing, } \\
\text { collaboration) } \\
\text { Tourism activities such as artificial snow } \\
\text { production and golf irrigation, irrigation in } \\
\text { agriculture and viticulture, housing types, } \\
\text { priority setting in regulations concerning } \\
\text { hydropower production and residual flow, } \\
\text { separation of drinking water and irrigation water } \\
\text { networks, and governance measures (water } \\
\text { rights, pricing, collaboration) }\end{array}$ \\
\end{tabular}

parameters and their assumed evolution within the four scenarios.

Lessons learned The first step-predefining necessary parameters for modelling-highlights the advantage of an iterative process when working simultaneously with scientists' and stakeholders' knowledge: it prevented the emergence of a gap between the stakeholders' development visions and the researchers' requirements from the very outset. The final selection of parameters has to be seen as a compromise between characterising the visions as clearly as possible, keeping the water use scenarios transparent, limited data availability, and the structural preconditions of the model applied (WEAP). The complexity of the visions had to be reduced, meaning that several aspects-namely the effects of changes in water rights, pricing, and institutional collaboration - had to be excluded from the water use scenarios. The biggest constraint, however, was not the gap between stakeholders' visions and the limitations of the water use model, but limited data availability. This was due partly to the fact that certain topics introduced by the stakeholders-such as different settlement developments (single family homes have a substantially higher water demand than apartment blocks, e.g. for garden irrigation) - had not been contemplated by the researchers at the outset of the study, and consequently data collection on this aspect had not been planned. The researchers dealt with this drawback by devising ways of estimating the respective data, for example by conducting small case studies mapping garden irrigation.

While this process included several simplifications and assumptions, the resulting quantification was highly appreciated by researchers and stakeholders. It enabled them to gain an overview of the most important leverage points. For instance, it became evident that the snow cannons use less water than had been claimed in public discussions.
Outlook: joint reflection on the results and their implications for sustainable water governance

In a next step, the scientists will systematically assess the four visions of future development and the related water use scenarios against sustainability values previously agreed upon in their team. This scientific perspective on sustainable water governance as well as the results of the water use models will then be presented to the RegiEau group, opening the floor for further discussions and mutual learning. Based on this transdisciplinary dialogue we will then deduce concrete options for sustainable water governance in the study region.

\section{Discussion and conclusions}

The objective of this article was to present a conceptual approach to transdisciplinary scenario building for sustainable water governance and to analyse its application in the MontanAqua project, taking into account the need for adequately valuing and linking the knowledge and needs of researchers and stakeholders. Our understanding of sustainable water governance as a broad societal learning process that contributes to more sustainable development also beyond the water sector led us to design and facilitate an intense collaboration process that combined a participatory scenario approach with normative and explorative approaches. In this article we focussed on the stakeholder processes and the interfaces where stakeholders' and researchers' knowledge was linked and transformed.

Overall, the designed participatory scenario approach was successful in that it enabled the co-construction of development visions and related water use scenarios, both of which provided relevant and novel knowledge to inform regional water governance.

In the beginning, several stakeholders and researchers were sceptical about the use of investing a lot of time in an extended participatory scenario process. Over time, however, the visions of regional development evolved into virtual "bridging objects" (Vinck 1999) between stakeholders and researchers, between local and regional levels, and between researchers from different disciplines. They acted as a link between the people involved, enabling them to exchange and create new knowledge in a continuous learning process.

Normative visions of regional development

Developing normative visions of sustainable regional development was useful not only in terms of the outcomes, but also in terms of the process itself: 
Table 7 Key parameters of the water use scenarios and their evolution according to the visions of regional development

\begin{tabular}{|c|c|c|c|c|c|}
\hline Key topics & Key parameters & Vision 1: growth strategy & $\begin{array}{l}\text { Vision 2: } \\
\text { stabilisation } \\
\text { strategy }\end{array}$ & $\begin{array}{l}\text { Vision 3: } \\
\text { moderation } \\
\text { strategy }\end{array}$ & $\begin{array}{l}\text { Vision of the } \\
\text { RegiEau group }\end{array}$ \\
\hline Demography & Number of inhabitants & Strongly increasing & $\begin{array}{l}\text { Slightly } \\
\text { increasing }\end{array}$ & Decreasing & $\begin{array}{l}\text { Slightly } \\
\text { increasing }\end{array}$ \\
\hline $\begin{array}{l}\text { Water } \\
\text { consumption }\end{array}$ & $\begin{array}{l}\text { Water demand per inhabitant } \\
\text { (drinking water, irrigation water) }\end{array}$ & Constant & Decreasing & $\begin{array}{l}\text { Strongly } \\
\text { decreasing }\end{array}$ & Decreasing \\
\hline \multirow[t]{2}{*}{$\begin{array}{l}\text { Spatial } \\
\text { planning }\end{array}$} & $\begin{array}{l}\text { Newly constructed houses (villas } \\
\text { and apartments) }\end{array}$ & $\begin{array}{l}\text { Strongly increasing, (especially } \\
\text { villas) Strongly increasing }\end{array}$ & $\begin{array}{l}\text { Slightly } \\
\text { increasing }\end{array}$ & Decreasing & $\begin{array}{l}\text { Slightly } \\
\text { increasing }\end{array}$ \\
\hline & Built-up area & & $\begin{array}{l}\text { Slightly } \\
\text { increasing }\end{array}$ & Constant & $\begin{array}{l}\text { Slightly } \\
\text { increasing }\end{array}$ \\
\hline \multirow[t]{6}{*}{ Tourism } & $\begin{array}{l}\text { Number of tourists (overnight } \\
\text { stays) }\end{array}$ & Slightly increasing & $\begin{array}{l}\text { Strongly } \\
\text { increasing }\end{array}$ & $\begin{array}{l}\text { Strongly } \\
\text { increasing }\end{array}$ & $\begin{array}{l}\text { Strongly } \\
\text { increasing }\end{array}$ \\
\hline & Water demand per tourist & Constant & Constant & Constant & Constant \\
\hline & Total surface of golf courses & Increasing & Constant & Decreasing & Constant \\
\hline & Water demand per unit & Constant & Constant & Constant & Constant \\
\hline & $\begin{array}{l}\text { Total surface of skiing areas with } \\
\text { artificial snow }\end{array}$ & Increasing & Constant & Zero & Constant \\
\hline & $\begin{array}{l}\text { Water demand for snow } \\
\text { production per unit }\end{array}$ & Constant & Decreasing & Zero & Decreasing \\
\hline \multirow[t]{3}{*}{ Agriculture } & Surfaces of irrigated grassland & Strongly decreasing & $\begin{array}{l}\text { Slightly } \\
\text { decreasing }\end{array}$ & $\begin{array}{l}\text { Strongly } \\
\text { decreasing }\end{array}$ & $\begin{array}{l}\text { Slightly } \\
\text { decreasing }\end{array}$ \\
\hline & Surfaces of irrigated cultures & Zero & Constant & $\begin{array}{l}\text { Strongly } \\
\text { increasing }\end{array}$ & $\begin{array}{l}\text { Slightly } \\
\text { increasing }\end{array}$ \\
\hline & $\begin{array}{l}\text { Demand for irrigation water per } \\
\text { unit }\end{array}$ & Constant & Constant & Constant & Constant \\
\hline \multirow[t]{3}{*}{ Viticulture } & Surfaces of irrigated vineyards & Increasing & $\begin{array}{l}\text { Slightly } \\
\text { decreasing }\end{array}$ & Increasing & $\begin{array}{l}\text { Slightly } \\
\text { decreasing }\end{array}$ \\
\hline & Irrigation technique & Sprinkler & Drip & Drip & Drip \\
\hline & $\begin{array}{l}\text { Demand for irrigation water per } \\
\text { unit }\end{array}$ & Constant & Decreasing & Decreasing & Decreasing \\
\hline \multirow[t]{4}{*}{ Hydropower } & $\begin{array}{l}\text { Natural water availability in the } \\
\text { catchment }\end{array}$ & Increasing & Increasing & Increasing & Increasing \\
\hline & $\begin{array}{l}\text { Water availability based on } \\
\text { artificial transfers }\end{array}$ & Increasing & Constant & Constant & Increasing \\
\hline & $\begin{array}{l}\text { Water reserved for drinking, } \\
\text { irrigation, residual flows }\end{array}$ & Decreasing & Increasing & Increasing & Increasing \\
\hline & $\begin{array}{l}\text { Water available for hydropower } \\
\text { production }\end{array}$ & Increasing & Increasing & Increasing & Increasing \\
\hline Nature & Residual flows & Decreasing & Constant & Increasing & Constant \\
\hline
\end{tabular}

(1) It enabled stakeholder involvement from the very outset; this made it possible to explore visions of the future that were strongly linked with stakeholders' everyday life, resulting in a feeling of ownership.

(2) It made explicit the fact that different stakeholders have different sustainability values, priorities, and development goals that guide their perspectives on what sustainable development in the region could be.

(3) It encouraged dialogue and reflection, resulting in the stakeholders' wish to construct a shared development vision.

(4) It led to a joint development vision, which can be seen as an important step towards formulating options for sustainable water governance. At the same time, it also clearly showed that there is disagreement in the region regarding the crucial question of water rights.

(5) It provided a sound reference for modelling potential future water use.

However, the process was also very challenging and had some limitations:

(1) Seeking normative visions, in the sense of desired futures, instead of exploring different possible evolutions according to a predefined hypothesis - as done in most other participatory scenario studies-requires that all participants be explicit about values. This 
makes the dialogue and the construction of coherent visions of the future much more demanding, especially in settings characterised by historical tensions, as was the case in our study.

(2) The visions of the future expressed by the stakeholders remained rather 'traditional' and close to everyday thinking. The participants remained strongly involved in their current activities, problems, and constraints.

\section{Explorative water use scenarios}

Translation of the visions of regional development into water use scenarios provided interesting and comprehensive scenarios that are strongly related to issues of interest to the stakeholders. One water use scenario even represents the shared vision of a stakeholder group pooling representatives of all main water users. However, translation of the qualitative visions into quantitative scenarios suitable for numeric modelling proved to be a very challenging task which requires substantial reduction, simplification, and assumptions. In this respect, our experiences correspond to the findings of other scenario studies trying to bridge the gap between people's visions and the potentials and limitations of numeric models and available data (Walz et al. 2007). Elaborating the visions and scenarios in an iterative process with both approaches informing each other helped to mitigate this problem.

While we agree with March et al. (2012) that we should try to further advance the models and enhance the data in order to improve the translation of qualitative visions into quantitative water use scenarios, we also believe that greater effort should be invested in finding ways to better 'link' qualitative and quantitative data, considering the equal value of the two types of data. In view of the overall objective of developing strategies for sustainable water governance, we wish to stress that jointly developing visions of regional development, including water governance issues, and quantifying water use scenarios are equally important. The calculation of water use scenarios improves the data base, thereby enabling more informed decisions. The vision process reveals stakeholders' competing visions more clearly, thereby demonstrating the need for shared visions in order to find regional solutions to water governance problems.

\section{Learning between stakeholders and researchers}

Linking normative and explorative scenario approaches in a participatory way enabled balanced cooperation between stakeholders and scientists, valuing their respective knowledge equally. The very early involvement of the stakeholders and the fact that both actor groups could influence the process was particularly valuable in this respect. While the results of the individual activities (e.g. first vision development workshop, scientific situation analyses) were not extremely innovative per se, the continuous process of collaboration and the effort to relate the different kinds of knowledge resulted in novel and inspiring insights which were appreciated by both actor groups. Throughout the process, they jointly reflected and debated on the present and possible future condition of the water governance system, what sustainable development in the region might be, and how current unsustainable arrangements and practices can be transformed to more sustainable ones. However-as a result of the pragmatic orientation of the whole endeavour-some scientists deplored that they restricted themselves in their scientific creativity.

The study further showed that fruitful co-production of knowledge between stakeholders and researchers:

- ... requires taking into account both stakeholders' and scientists' interests and needs. To stakeholders it proved to be important that their realities, values, and development aims are duly considered; the researchers considered crucial that the scenarios be suitable for numeric modelling and scientific reflection. Both actor groups strove for new and inspiring insights beyond their normal ways of thinking, which they could only obtain by learning from each other.

- ... requires thorough planning and flexible open-ended moderation of the process in order to prevent too big a gap between the actors involved. However, it also requires researchers' willingness to respond to stakeholders' contributions, including a high amount of flexibility and creativity. A major challenge in this respect is the difference in the time horizons of stakeholders and researchers (for example, the stakeholders would have liked to continue their search for a shared development vision, while the $\mathrm{PhD}$ students needed to complete their studies within the funding period of 3 years).

- ... should not strive for integrating different kinds of knowledge in a single model (e.g. by the scientists) as an end in itself, but should be seen as part of an overall societal learning process (Alroe and Noe 2010) in which researchers' and scientists' knowledge informs a deliberative dialogue. A mixed approach that makes it possible to capture stakeholders' genuine knowledge and feed it into a scientific analysis, which is then fed back into the deliberative dialogue, can prevent scientists' and stakeholders' roles and identities from becoming too fuzzy and encourages them to fully explore the learning potentials that a dialogue between different forms of knowledge holds. 
The examples given show that shifts from strategic to communicative action are possible in an environment of mutual trust. This ultimately depends on creating conditions of interaction that are based on the equality of scientists' and stakeholders' knowledge.

Acknowledgments This project is affiliated to the NRP61 (Sustainable water management). The authors wish to thank the MontanAqua research team and the members of the stakeholder group RegiEau for helpful assistance, fruitful discussions and inspiring collaboration. We also express our gratitude to Marlène Thibault for English proof reading of the manuscript.

\section{References}

Aeberhard A, Rist S (2009) Transdisciplinary co-production of knowledge in the development of organic agriculture in Switzerland. Ecol Econ 68:1171-1181

Alcamo J (2008) Developments in integrated environmental assessment. In: Joseph A (ed) The SAS approach: combining qualitative and quantitative knowledge in environmental scenarios. Elsevier, Amsterdam, pp 123-150

Alroe HF, Noe E (2010) Multiperspectival science and stakeholder involvement: beyond transdisciplinary integration and consensus. In: Darnhofer I, Grötzer M (eds), Building sustainable rural futures. Proceedings of the 9th European IFSA Symposium 4-7 July 2010, Vienna (Austria), pp 527-533

Beniston M, Stoffel M, Hill M (2011) Impacts of climatic change on water and natural hazards in the Alps: can current water governance cope with future challenges? Examples from the European "ACQWA" project. Environ Sci Policy 14:734-743

Bonriposi M (2013) Analyse systémique et prospective des usages de l'eau dans la region de Crans-Montana-Sierre (Suisse). Thèse de doctorat. Université de Lausanne, Institut de Géographie et Durabilité, Géovisions

Checkland P, Holwell S (1998) Action research: its nature and validity. Syst Pract Act Res 11(1):9-21

Cosgrove CE, Cosgrove WJ (2012) The United Nations World Water Development Report-No 4. The dynamics of global water futures: driving forces 2011-2050, vol 2. UNESCO

Daniell KA, White I, Ferrand N, Ribarova IS, Coad P, Rougier J-E, Hare M, Jones NA, Popova A, Rollin P, Perez P, Burn S (2010) Co-engineering participatory water management processes: theory and insights from Australian and Bulgarian interventions. Ecol Society 15(4):11. Available at: http://www.ecologyand society.org/vol15/iss4/art11/. Accessed on 26 August 2013

Du Toit DR, Biggs H, Pollard S (2011) The potential role of mental model methodologies in multistakeholder negotiations: integrated water resources management in South Africa. Ecol Soc 16(3):21

Elden M, Levin M (1991) Cogenerative learning: bringing participation into action research. In: Whyte WF (ed) Participatory action research. Sage Publications, Newbury Park, pp 127-142

Flick U (2005) Qualitative Sozialforschung. Eine Einfuehrung. Reinbek bei Hamburg, Rowohlt Taschenbuch

Forsyth S, Brooks DB (2011) Applying water soft path analysis in an agricultural region of Canada. Water Int 36:894-907

Franks T, Cleaver F (2009) Analysing water governance: a tool for sustainability? Proc Inst Civil Eng Eng Sustain 162:207-213

GEF (2013) TDA/SAP Methodology. Identify, quantify, and set priorities for environmental transboundary problems. Webversion http://manuals.iwlern.net/tda-sap-methodology Accessed on 26 August 2013
Gibbons M, Limoges C, Nowotny H, Schwartzman S, Scott P, Trow M (1994) The new production of knowledge the dynamics of science and research in contemporary societies. Sage, London

Harmancioglu NB, Fedra K, Barbaros F (2008) Analysis for sustainability in management of water scarce basins: the case of the Gediz River Basin in Turkey. Desalination 226:175-182

Hartmuth G, Huber K, Rink D (2008) Operationalization and contextualization of sustainability at the local level. Sustain Dev 16:261-270

Hirsch Hadorn G, Bradley D, Pohl C, Rist S, Wiesmann U (2006) Implications of transdisciplinarity for sustainability research. Ecol Econ 60:119-128

ISSKA (2010) Bassins versants karstiques et modèles 3D autour de Montana. Version provisoire. Internal report

Kim J, Furumai H (2012) Assessment of rainwater availability by building type and water use through GIS-based scenario analysis. Water Resour Manage 26:1499-1511

Kok K, van Vliet M, Bärlund I, Dubel A, Sendzimir J (2011) Combining participative backcasting and exploratory scenario development: experiences from the SCENES project. Technol Forecast Soc Change 78:835-851

Kuylenstierna JL, Björklund G, Najlis P (1997) Sustainable water future with global implications: everyone's responsibility. Nat Resour Forum 21:181-190

Lawhon M, Murphy JT (2012) Socio-technical regimes and sustainability transitions: insights from political ecology. Prog Hum Geogr 36:354-378

Lienert J, Monstadt J, Truffer B (2005) Future scenarios for a sustainable water sector: a case study from Switzerland. Environ Sci Technol 40:436-442

March H, Therond O, Leenhardt D (2012) Water futures: reviewing water-scenario analyses through an original interpretative framework. Ecol Econ 82:126-137

Mobjörk M (2010) Consulting versus participatory transdisciplinarity: a refined classification of transdisciplinary research. Futures 42:866-873

Moran D, MacLeod M, McVittie A, Lago M, Oglethorpe D (2007) Dynamics of water use in Scotland. Water Environ J 21:241-251

Moriarty PB, Batchelor CH, Laban P, Fahmy H (2010) Developing a practical approach to 'light IWRM' in the Middle East. Water Altern 3:122-136

Mylopoulos N, Kolokytha E, Loukas A, Mylopoulos Y (2012) Agricultural and water resources development in Thessaly, Greece in the framework of new European Union policies. Int $\mathbf{J}$ River Basin Manag 7:73-89

Nassauer JI, Corry RC (2004) Using normative scenarios in landscape ecology. Landsc Ecol 19:343-356

Niklaus M (2012) An object-oriented approach for mapping current land use/land cover in the study area Crans-Montana-Sierre, Valais. Masterarbeit der Universität Bern, Schweiz

Nowotny H (2000) Re-thinking science: from reliable to socially robust knowledge. In: Weiss M (ed) Jahrbuch 2000 des Collgeium Helveticum der ETH Zürich. vdf, Zürich, pp 221-244

Nowotny H, Gibbons M, Scott P (2001) Re-thinking science: knowledge and the public in an age of uncertainty. Polity, Cambridge

Palomo I, Marín-López B, López-Santiago C, Montes C (2011) Participatory scenario planning for protected areas management under the ecosystem services framework: the Doñana socialecological system in Southwestern Spain. Ecol Soc 16(1):23. Available at: http://www.ecologyandsociety.org/vol16/iss11/ $\operatorname{art23/}$

Pohl C, Hirsch Hadorn G (2007) Principles for designing transdisciplinary research. Oekom, Munich

Pollard S, Du Toit D (2008) Integrated water resource management in complex systems: how the catchment management strategies 
seek to achieve sustainability and equity in water resources in South Africa. Water SA (IWRM Special Edition) 34(6). Available at http://www.wrc.org.za

Ray C (1999) Endogenous development in the era of reflexive modernity. J Rural Stud 15(3):257-267

Reed MS (2008) Stakeholder participation for environmental management: a literature review. Biol Conserv 141:2417-2431

Renner R, Schneider F, Hohenwallner D, Kopeinig C, Kruse S, Lienert J, Link S, Muhar S (2013) Meeting the challenges of transdisciplinary knowledge production for sustainable water governance. Mt Res Dev 33(3):234-247

Reynard E (2000) Gestion patrimoniale et intégrée des ressources en eau dans les stations touristiques de montagne. Les cas de CransMontana-Aminona et Nendaz (Valais). Thèse présentée à la Faculté des Lettres de l'Université de Lausanne

Reynard E, Bonriposi M (2012) Water use management in dry mountains of Switzerland: the case of Crans-Montana-Sierre area. In: Nemenyi M, Heil B (eds) The impact of urbanization, industrial, agricultural and forest technologies on the natural environment. Nyugat-Magyarorszagi Egytem Sopron, Hungary, pp 281-301

Rinaudo JD, Montginoul M, Varanda M, Bento S (2012) Envisioning innovative groundwater regulation policies through scenario workshops in France and Portugal. Irrigation Drainage 61:65-74

Rist S, Chiddambaranathan M, Escobar C, Wiesmann U (2006) "It was hard to come to mutual understanding..." Multidimensionality of social learning processes in natural resource use in India, Africa and Latin America. J Syst Pract Action Res 19:219-237

Rist S, Chiddambaranathan M, Escobar C, Wiesmann U, Zimmermann A (2007) Moving from sustainable management to sustainable governance of natural resources: the role of social learning processes in rural India, Bolivia and Mali. J Rural Stud 23:23-37

Roux DJ, Rogers KH, Biggs HC, Ashton PJ, Sergeant A (2006) Bridging the science-management divide: moving from unidirectional knowledge transfer to knowledge interfacing and sharing. Ecol Soc 11: Article 4. Available at: http://www. ecologyandsociety.org/vol11/iss11/art14/

Schaldach R, Koch J, Aus der Beek T, Kynast E, Flörke M (2012) Current and future irrigation water requirements in pan-Europe: an integrated analysis of socio-economic and climate scenarios. Glob Planet Change 94-95:33-45

Schneider F (2011) Approaching water stress in the Alps: Transdisciplinary co-production of systems, target and transformation knowledge. In: Borsdorf A, Stötter J, Veulliet E (eds) Managing Alpine Future II-Inspire and drive sustainable mountain regions. Proceedings of the Innsbruck Conference, November 21-23, 2011. (=IGF-Forschungsberichte 4). Verlag der Österreichischen Akademie der Wissenschaften, Vienna

Schneider F, Fry P, Ledermann T, Rist S (2009) Social learning processes in Swiss soil protection-The 'From Farmer-To Farmer' project. Hum Ecol 37:475-489

Smits S, Pollard S, Du Toit D, Butterworth J, Moriarty P (2004) Modelling scenarios for water resources management in the Sand River Catchment, South Africa (WHIRL Project working paper; no. 8). NRI, Chatham, UK

Soliva R (2007) Agricultural decline, landscape change, and outmigration: debating the sustainability of three scenarios for a Swiss mountain region. Mt Res Develop 27:124-129

Soliva R, Ronningen K, Bella I, Bezak P, Cooper Tamsin, Egil Flo B, Marty P, Potter C (2008) Envisioning upland futures: stakeholder responses to scenarios Europe's mountain landscapes. J Rural Stud 24:56-71

Strauss AL, Corbin JM (1997) Grounded theory in practice. Sage, Thousand Oaks

Swart RJ, Raskin P, Robinson J (2004) The problem of the future: sustainability science and scenario analysis. Glob Environ Change 14:137-146

Vinck D (1999) Les objets intermédiaires dans les réseaux de coopération scientifique. Contribution à la prise en compte des objets dans les dynamiques sociales. Rev Fr Sociol 2:385-414

Viviroli D, Archer DR, Buytaert W, Fowler HJ, Greenwood GB, Hamlet AF, Huang Y, Koboltschnig G, Litaor MI, LopezMoreno JI, Lorentz S, Schädler B, Schreier H, Schwaiger K, Vuille M, Woods R (2011) Climate change and mountain water resources: overview and recommendations for research, management and policy. Hydrol Earth Syst Sci 15:471-504

Voinesco A (2012) Le glacier de la Plaine-Morte: épaisseur de glace et bilan de masse. Msc Thesis, University of Fribourg

Walz A, Lardelli C, Behrendt H, Grêt-Regamey A, Lundström C, Kytzia S, Bebi P (2007) Participatory scenario analysis for integrated regional modelling. Landsc Urban Plan 81:114

WCED (1987) Report of the World commission on environment and development: our common future. http://www.un-documents. net/wced-ocf.htm. Accessed 28 January 2013

Wiek A, Larson K (2012) Water, people, and sustainability-a systems framework for analyzing and assessing water governance regimes. Water Resour Manage 26:3153-3171

Wollenberg E, Edmunds D, Buck L (2000) Using scenarios to make decisions about the future: anticipatory learning for the adaptive co-management of community forests. Landsc Urban Plan 47:65 